\title{
Influence of mineral fertilizers on economic indicators of cultivated varieties of spring triticale in the conditions of the republic of Mari EI
}

\author{
V. A. Maksimov*, Y. A. Lapsyin, R. I. Zolotareva, R. B. Maksimova \\ Federal Agricultural ResearchCenter of the North-East named after N.V. Rudnitsky, Kirov, Russian Federation
}

\begin{abstract}
In modern socio-economic conditions, the production of high-quality grain remains the main task of agricultural production. The main way to solve it is to increase productivity by introducing new varieties and crops with high potential and improving the cultivation technology with minimal costs. Agrarians of the North-East of the Non-Chernozem Zone of Russia, having in their land, use poorly fertile sod-podzolic soils of varying degrees of cultivation. To increase the productivity of grain crops, they use adapted resource-saving technologies, in which the level of mineral fertilizer is determined by the magnitude of the dose of the nutrient established experimentally. The high productivity of the variety, along with the quality of the grain, is the most important indicator of the ultimate goal of every breeder. To assess the economic efficiency of the cultivation of spring triticale, studies were carried out on nine varieties: Saur, Dobroe, Zaozerye, KNIISH 9, KNIISH 11, KNIISH 22, Savva, Timur, Rovnya. The results of our studies convincingly indicate that in the conditions of the republic, even against an unfertilized background, cultivated varieties of spring triticale, provide grain yield from 2.5 to $3.8 \mathrm{t} / \mathrm{ha}$. Some of the most important economic indicators characterizing production efficiency are such indicators as the cost of production and the degree of efficiency of grain production, expressed by the level of profitability. The main application of mineral fertilizers $\left(\mathrm{N}_{60} \mathrm{P}_{60} \mathrm{~K}_{60},\left(\mathrm{P}_{60} \mathrm{~K}_{60}\right)\right.$ and the introduction of nitrogen fertilization in tillering at a dose of $\mathrm{N}_{30}$ increases the cost of $1 \mathrm{~kg}$ of grain by $5-8 \%$, thereby reducing the profitability of production when cultivating varieties. The cultivation of varieties Rovnya, Zaur, Zaozerye, KNIISH 22, KNIISH 11, Timur was economically profitable, but less profitable than varieties KNIISH 9, Dobroe and Savva. The cost of production of a kilogram of grain was on the option without mineral nutrition from $5.1 ; 7.0 ; 5.9 ; 5.1 ; 4.8$; and 6.4 rubles, respectively. On fertilized options, the cost decreased to a minimum of 4.1 rubles in the Timur variety with the main application of $\mathrm{N}_{60} \mathrm{P}_{60} \mathrm{~K}_{60}$ with nitrogen fertilization $\mathrm{N}_{30}$ during tillering. The maximum increase in the cost price was shown by the varieties Timur, Zaozerye: 4.8 and 4.9 rubles against the background of the main application of $\mathrm{N}_{60} \mathrm{P}_{60} \mathrm{~K}_{60}$. On average for 2020 according to the results of economic analysis, the lowest cost price and the highest level of profitability indicator are observed when cultivating varieties KNIISH 9, Dobroe and Savva at all levels of mineral nutrition.
\end{abstract}

\section{Introduction}

The main task of agriculture in modern socio-economic conditions is the production of high-quality grain. The main way to solve it is to increase productivity by introducing new crops and varieties with high adaptive potential and improving the cultivation technology with minimal costs. Along with traditional grain crops, triticale is cultivated in many regions of the country. Interest in this culture has increased due to the unique combination of its economic and biological features: high ecological plasticity of rye with the yield and quality of wheat. The undoubted advantage of triticale is the possibility of its use in two directions - food and feed. Triticale is less demanding on soils compared to wheat, has high winter hardiness and drought resistance, increased immunity to a number of fungal and viral diseases, so the seeds do not need to be etched with chemicals and disinfected by a complex thermal method before sowing [1].

The leading branch of agriculture in the Republic of Mari El is animal husbandry, which, in order to further increase the volume of food production, needs a strong and stable fodder base. One of the reserves for replenishing the fodder base of grain crops is the use of triticale grain. In recent years, serious large-scale work has been carried out on the selection of both winter and spring species of this crop. Its high adaptive ability to consistently produce high grain yields, agrotechnical significance in crop rotation, characterize triticale as a crop of low economic risk.

A feature of triticale as a crop is the ability to use a wide range of technologies and technological operations developed by scientists for the cultivation of wheat. This

\footnotetext{
* Corresponding author: via@mari-el.ru
} 
is an important characteristic for a relatively new crop, since with its introduction into crop rotations the producer does not need to invest in the development of new technological techniques. Culture makes it possible to more effectively use the experience gained in the cultivation of other cereals in combination with the latest recommendations of scientists, the differentiation of farms by financial and economic opportunities.

Land in agriculture is the main means of production, the features of which (fertility, microclimate, relief, location, etc.) largely determine the differences in the efficiency of production costs in different types of farms. The economic efficiency of agricultural production and its adaptability is based on the differentiated use of natural factors, which are unevenly distributed in time and space, limiting the size and quality of the harvest [2, 3].Agrarians of the North-East of the Non-Chernozem Zone of Russia, having in their land use poorly fertile sod-podzolic soils of varying degrees of cultivation, to increase the productivity of grain crops, use adapted resource-saving technologies, in which the level of mineral fertilizer is determined by the magnitude of the dose of the nutrient established experimentally.

According to the available experimental data obtained under the conditions of the republic, one of the most significant factors in increasing the yield and quality of grain is a balanced supply of plants with mineral nutrition elements, especially nitrogen $[4,5]$. For the normal growth and development of spring triticale plants, nitrogen is of primary importance. Like all cereals, triticale needs nitrogen nutrition from an early period of development. This is due to the need to form a well-developed leaf surface, which is responsible for the formation of assimilants in plants. If during this period there is not enough nitrogen, then an insufficiently developed leaf apparatus is formed, which is reflected in the size and quality of the yield. However, an excessive amount of nitrogen during this period can lead to a decrease in grain yield due to the development of vegetative mass and mutual shading of plants [6].

In modern conditions of agriculture, the role of the variety is also increasing, which, along with the use of mineral fertilizers, is the main means of ensuring high productivity of grain crops with the timely and highquality implementation of other agrotechnical methods. A well-organized grain farming increases the efficiency of agricultural production in general.

The most important estimated indicators of the effectiveness of products are cost and profitability. It is known that the profitability of industrial technologies in agriculture is provided only if the purchase prices outstrip the growth in the cost of an additional crop, that is, they compensate for the decrease in the profitability of using more and more fertilizers, pesticides, ameliorants and other technogenic factors [7].

The areas where spring triticale is sown in the Republic of Mari El are clearly small and insufficient, and in the structure of sown areas they make up no more than $0.5 \%$. The success of modern breeding translates triticale into a number of the most economically popular forage crops.
Due to the adaptability of triticale to growing conditions and a much greater yield potential on depleted soils, it makes more rational use of available soil and climatic resources. The size of the crop and the quality of triticale grain are primarily determined by the biological characteristics of the variety and the conditions of mineral fertilization of plants. At the same time, it is possible to control the level of yield and the quality of the produced grain through the nutrition regime and the seeding rates of the crop. Both of these factors are insufficiently studied in the conditions of the Republic of Mari El. Therefore, the optimal parameters of these factors need to be clarified in relation to the new generation of highly productive spring triticale varieties that have appeared in recent years.

The need to develop a technology for growing spring triticale adapted to the conditions of the republic, revealing its potential as a grain fodder crop and ensuring stable production of high-quality grain products at the level of 3-4t/ha, is an urgent task.

Based on the above, the Department of seed production of the Mari NIISH - branch of the FGBNU FANC of the North-East conducted studies to determine the economic assessment of growing different varieties of spring triticale.

\section{Materials and methods}

The research was carried out in the fields of the Mari Research Institute of Agriculture - a branch of the FBGNU FANTS of the North-East in 2020.

The agricultural technology of cultivation of spring triticale is generally accepted for the conditions of the Republic of Mari El. The soil of the experimental site is sod-podzolic medium loamy. At the time of the experiment, the arable layer was characterized by the following agrochemical indicators: humus content (according to Tyurin) $-3.2 \%$, total nitrogen $-0.19 \%, \mathrm{pH}$ of the aqueous suspension- $6.1 \%$, the hydrolytic acidity index was $4.7 \mathrm{mg}$-eq $/ 100 \mathrm{~g}$ of soil, the sum of absorbed bases-7.9 mg-eq/100g of soil.

The content of mobile phosphorus in the soil was in the range of $603 \mathrm{mg}$, and the content of exchangeable potassium was $142 \mathrm{mg}$ per $1 \mathrm{~kg}$ of soil. The studies were accompanied by the study of environmental factors, agrochemical analyses of soil and plants, during the growing season marked the onset of phenological phases of plant development, took into account the structure, yield and quality of spring triticale.

The object of research is 9 varieties of spring triticale. The purpose of the research is to identify the most productive and economically viable options for applying the norms of mineral fertilizers on sod-podzolic soils of the Euro-North-East region of Russia. Experience scheme is presented in Tables 1 and 2.

The setting of the field experiment and statistical processing of the yield data were carried out by the method of analysis of variance according to the method of B.A. Dospekhova. Observations and records in field experiments - according to the methodology of state variety testing of agricultural crops- [8]. The economic 
efficiency was calculated according to the methodological recommendations developed by $\mathrm{P}$. Kokurin, N.N. Prokhorova [9], taking into account the actual costs. The cost of manufactured products was determined by the calculation method, by multiplying the size of the crop by the average market price of products that developed on the market of the republic during the years of research. All tested varieties were sown at a seeding rate of 6 million viable seeds per hectare.

Table 1. Factor A - varieties of spring triticale:

\begin{tabular}{|l|l|}
\hline Variety & Organization originator \\
\hline 1.Saur & $\begin{array}{l}\text { FGBNU Federal Rostov } \\
\text { agricultural research center }\end{array}$ \\
\hline 3.Dobroye & $\begin{array}{l}\text { FGBNU Verkhnevolzhsky } \\
\text { FANTS, RUE Scientific and } \\
\text { Practical Center of the National } \\
\text { Academy of Sciences of Belarus } \\
\text { for Agriculture }\end{array}$ \\
\hline 4.KNIISH9* $*$ & $\begin{array}{l}\text { FGBNU Verkhnevolzhsky } \\
\text { FANTS, RUE Scientific and } \\
\text { Practical Center of the National } \\
\text { Academy of Sciences of Belarus } \\
\text { for Agriculture }\end{array}$ \\
\hline 5.KNIISH 11* & $\begin{array}{l}\text { FSBS National Grain Center } \\
\text { named after P.P. Lukyanenko } \\
\text { named after P.P. Lukyanenko }\end{array}$ \\
\hline 6.KNIISH 22* & $\begin{array}{l}\text { FSBSI National Grain Center } \\
\text { named after P.P. Lukyanenko }\end{array}$ \\
\hline 7.Savva & $\begin{array}{l}\text { FSBSI National Grain Center } \\
\text { named after P.P. Lukyanenko }\end{array}$ \\
\hline 8.Timur & $\begin{array}{l}\text { FSBSI National Grain Center } \\
\text { named after P.P. Lukyanenko }\end{array}$ \\
\hline 9.Rovnya & $\begin{array}{l}\text { FGBNU Verkhnevolzhsky } \\
\text { FANTS, FGBNU National Grain } \\
\text { Center named after P.P. } \\
\text { Lukyanenko }\end{array}$ \\
\hline
\end{tabular}

Note: * Introduced into the test scheme from 2020.

* Variety Rovnya $(\mathrm{St}) *$ approved for use in the VolgaVyatka region and adopted as a standard at the variety testing sites of the Republic of Mari El.

Table 2. Factor B - mineral fertilizers

\begin{tabular}{|l|l|}
\hline Variants & Doses of mineral fertilizers \\
\hline B 1 & without fertilizers \\
\hline B 2 & $\mathrm{N}_{60} \mathrm{P}_{60} \mathrm{~K}_{60}$ \\
\hline B 3 & $\mathrm{N}_{60} \mathrm{P}_{60} \mathrm{~K}_{60}+\mathrm{N}_{30}$ tillering \\
\hline B 4 & $\mathrm{P}_{60} \mathrm{~K}_{60}+\mathrm{N}_{30}$ tillering \\
\hline B 5 & $\mathrm{N}_{30}$ tillering \\
\hline
\end{tabular}

\section{Results and Discussion}

One of the most important areas of scientific and technological progress in modern agricultural production is the wider development of resource-saving adaptive technologies that can significantly increase the yield of products, improve their quality, reduce labor and money costs, and create conditions for sustainable grain production.

The high yield of the variety, along with the quality of the grain, is the most important indicator of the ultimate goal of every breeder. The results of our research convincingly indicate that under the conditions of the republic, even against a background without fertilization, the cultivated varieties of spring triticale provide grain yield from 2.5 to $3.8 \mathrm{t} / \mathrm{ha}$.

Some of the most important economic indicators that characterize production efficiency are such indicators as the cost of production and the degree of efficiency of grain production, which is expressed by the level of profitability. The table shows data on the cost price and the level of profitability of cultivating varieties of spring triticale on average for 2020.

Under the prevailing agro-climatic conditions for the growing year, the tested varieties showed different grain productivity, therefore, different costs and the level of production profitability. In the table the results of calculating the economic efficiency showed that the cultivation of spring triticale in all variants of the experiment was profitable.

The smallest values of cost and profitability were noted for the variety KNIISH 9 from 3.7 rubles against the background of the main application of $\mathrm{N}_{60} \mathrm{P}_{60} \mathrm{~K}_{60}$ and up to 4.6 rubles without mineral fertilizers with a profitability level of $170 \%$ to $115 \%$, for the Dobroe variety these indicators were from 4.0 rubles against the background of the main application of $\mathrm{N}_{60} \mathrm{P}_{60} \mathrm{~K}_{60}$ up to 5.7 rubles without mineral fertilizers, with a profitability of $153 \%$ to $77 \%$, respectively.

The same low indicators are observed for the Savva variety: from 4.2 rubles against the background of the main application of $\mathrm{P}_{60} \mathrm{~K}_{60}$ up to 4.5 rubles without mineral nutrition, the level of profitability ranged from $140 \%$ to $124 \%$, respectively, relative to other tested varieties. The main application of $\mathrm{N}_{60} \mathrm{P}_{60} \mathrm{~K}_{60}, \mathrm{P}_{60} \mathrm{~K}_{60}$ and the introduction of nitrogen fertilization in the tillering phase at a dose of $\mathrm{N}_{30}$ increases the cost of $1 \mathrm{~kg}$. grain by $5-8 \%$, thereby reducing the profitability of production when cultivating varieties.

The cultivation of the varieties Rovnya, Zaur, Zaozerye, KNIISH 22, KNIISH 11, Timur was economically profitable, but less profitable: the cost of producing a kilogram of grain on options without mineral nutrition was $7.0 ; 5.9 ; 5.1 ; 4.8$ and 6.4 rubles respectively. On fertilized options, the minimum cost value was for the Timur - 4.1 rubles variety with the main application of $\mathrm{N}_{60} \mathrm{P}_{60} \mathrm{~K}_{60}$ with nitrogen fertilization $\mathrm{N}_{30}$ in the tillering phase. The maximum increase in prime cost was shown by the varieties Timur, Zaozerye 4.8 and 4.9 rubles against the background of the main application of $\mathrm{N}_{60} \mathrm{P}_{60} \mathrm{~K}_{60}$. 
Table 3. Economic assessment of the efficiency of cultivation of spring triticale varieties for 2020 .

\begin{tabular}{|c|c|c|c|c|c|}
\hline Variety & level of mineral nutrition & $\begin{array}{c}\text { Production cost, } \\
\text { thousand rubles. } \\
(1 \mathrm{~kg}-10 \mathrm{rub})\end{array}$ & $\begin{array}{l}\text { Costs per hectare, } \\
\text { thousand rubles }\end{array}$ & $\begin{array}{l}\text { Cost price for } \\
1 \mathrm{~kg} \text { of grain, } \\
\text { rub. }\end{array}$ & $\begin{array}{c}\text { Profitability } \\
\text { level, } \%\end{array}$ \\
\hline \multirow{5}{*}{$\begin{array}{l}\text { Rovnya } \\
\text { (St) }\end{array}$} & No fertilizers. & 33.6 & 17.2 & 5.1 & 95 \\
\hline & $\mathrm{N}_{60} \mathrm{P}_{60} \mathrm{~K}_{60}$ & 43.6 & 19.2 & 4.4 & 127 \\
\hline & $\mathrm{N}_{60} \mathrm{P}_{60} \mathrm{~K}_{60}+\mathrm{N}_{30}$ & 44.7 & 19.8 & 4.4 & 126 \\
\hline & $\mathrm{P}_{60} \mathrm{~K}_{60}+\mathrm{N}_{30}$ & 42.2 & 19.1 & 4.5 & 121 \\
\hline & $\mathrm{N}_{30}$ & 40.3 & 17.8 & 4.4 & 126 \\
\hline \multirow{5}{*}{ Saur } & No fertilizers. & 25.0 & 17.2 & 7.0 & 45 \\
\hline & $\mathrm{N}_{60} \mathrm{P}_{60} \mathrm{~K}_{60}$ & 42.9 & 19.2 & 4.5 & 123 \\
\hline & $\mathrm{N}_{60} \mathrm{P}_{60} \mathrm{~K}_{60}+\mathrm{N}_{30}$ & 44.4 & 19.8 & 4.5 & 124 \\
\hline & $\mathrm{P}_{60} \mathrm{~K}_{60}+\mathrm{N}_{30}$ & 42.3 & 19.1 & 4.5 & 122 \\
\hline & $\mathrm{N}_{30}$ & 39.4 & 17.8 & 4.5 & 121 \\
\hline \multirow{5}{*}{ Dobroye } & No fertilizers. & 30.4 & 17.2 & 5.7 & 77 \\
\hline & $\mathrm{N}_{60} \mathrm{P}_{60} \mathrm{~K}_{60}$ & 48.5 & 19.2 & 4.0 & 153 \\
\hline & $\mathrm{N}_{60} \mathrm{P}_{60} \mathrm{~K}_{60}+\mathrm{N}_{30}$ & 46.7 & 19.8 & 4.2 & 140 \\
\hline & $\mathrm{P}_{60} \mathrm{~K}_{60}+\mathrm{N}_{30}$ & 45.5 & 19.1 & 4.2 & 138 \\
\hline & $\mathrm{N}_{30}$ & 43.3 & 17.8 & 4.1 & 143 \\
\hline \multirow{5}{*}{ Zaozerye } & No fertilizers. & 29.3 & 17.2 & 5.9 & 70 \\
\hline & $\mathrm{N}_{60} \mathrm{P}_{60} \mathrm{~K}_{60}$ & 39.5 & 19.2 & 4.9 & 106 \\
\hline & $\mathrm{N}_{60} \mathrm{P}_{60} \mathrm{~K}_{60}+\mathrm{N}_{30}$ & 40.7 & 19.8 & 4.7 & 106 \\
\hline & $\mathrm{P}_{60} \mathrm{~K}_{60}+\mathrm{N}_{30}$ & 41.1 & 19.1 & 4.6 & 115 \\
\hline & $\mathrm{N}_{30}$ & 40.4 & 17.8 & 4.4 & 127 \\
\hline \multirow{5}{*}{$\begin{array}{l}\text { KNIISH } \\
22\end{array}$} & No fertilizers. & 33.4 & 17.2 & 5.1 & 94 \\
\hline & $\mathrm{N}_{60} \mathrm{P}_{60} \mathrm{~K}_{60}$ & 42.7 & 19.2 & 4.5 & 122 \\
\hline & $\mathrm{N}_{60} \mathrm{P}_{60} \mathrm{~K}_{60}+\mathrm{N}_{30}$ & 42.5 & 19.8 & 4.7 & 115 \\
\hline & $\mathrm{P}_{60} \mathrm{~K}_{60}+\mathrm{N}_{30}$ & 43.0 & 19.1 & 4.4 & 125 \\
\hline & $\mathrm{N}_{30}$ & 40.6 & 17.8 & 4.4 & 128 \\
\hline \multirow{5}{*}{$\begin{array}{l}\text { KNIISH } \\
11\end{array}$} & No fertilizers. & 35.6 & 17.2 & 4.8 & 107 \\
\hline & $\mathrm{N}_{60} \mathrm{P}_{60} \mathrm{~K}_{60}$ & 46.1 & 19.2 & 4.2 & 140 \\
\hline & $\mathrm{N}_{60} \mathrm{P}_{60} \mathrm{~K}_{60}+\mathrm{N}_{30}$ & 46.4 & 19.8 & 4.3 & 134 \\
\hline & $\mathrm{P}_{60} \mathrm{~K}_{60}+\mathrm{N}_{30}$ & 44.6 & 19.1 & 4.3 & 134 \\
\hline & $\mathrm{N}_{30}$ & 40.0 & 17.8 & 4.5 & 125 \\
\hline \multirow{5}{*}{ KNIISH 9} & No fertilizers. & 37.0 & 17.2 & 4.6 & 115 \\
\hline & $\mathrm{N}_{60} \mathrm{P}_{60} \mathrm{~K}_{60}$ & 51.8 & 19.2 & 3.7 & 170 \\
\hline & $\mathrm{N}_{60} \mathrm{P}_{60} \mathrm{~K}_{60}+\mathrm{N}_{30}$ & 51.8 & 19.8 & 3.8 & 162 \\
\hline & $\mathrm{P}_{60} \mathrm{~K}_{60}+\mathrm{N}_{30}$ & 47.1 & 19.1 & 4.1 & 147 \\
\hline & $\mathrm{N}_{30}$ & 42.9 & 17.8 & 4.1 & 141 \\
\hline \multirow{5}{*}{ Savva } & No fertilizers. & 38.5 & 17.2 & 4.5 & 124 \\
\hline & $\mathrm{N}_{60} \mathrm{P}_{60} \mathrm{~K}_{60}$ & 45.6 & 19.2 & 4.2 & 138 \\
\hline & $\mathrm{N}_{60} \mathrm{P}_{60} \mathrm{~K}_{60}+\mathrm{N}_{30}$ & 46.9 & 19.8 & 4.2 & 137 \\
\hline & $\mathrm{P}_{60} \mathrm{~K}_{60}+\mathrm{N}_{30}$ & 45.9 & 19.1 & 4.2 & 140 \\
\hline & $\mathrm{N}_{30}$ & 42.3 & 17.8 & 4.2 & 138 \\
\hline \multirow{5}{*}{ Timur } & No fertilizers. & 27.0 & 17.2 & 6.4 & 57 \\
\hline & $\mathrm{N}_{60} \mathrm{P}_{60} \mathrm{~K}_{60}$ & 40.3 & 19.2 & 4.8 & 110 \\
\hline & $\mathrm{N}_{60} \mathrm{P}_{60} \mathrm{~K}_{60}+\mathrm{N}_{30}$ & 47.8 & 19.8 & 4.1 & 141 \\
\hline & $\mathrm{P}_{60} \mathrm{~K}_{60}+\mathrm{N}_{30}$ & 44.7 & 19.1 & 4.3 & 134 \\
\hline & $\mathrm{N}_{30}$ & 37.6 & 17.8 & 4.7 & 111 \\
\hline
\end{tabular}

\section{Conclusion}

Thus, on average for 2020, according to the results of economic analysis, the lowest cost and the highest level of profitability indicator are observed when cultivating the KNIISH variety $9-3.7$ rubles with the variant with the main application of mineral fertilizers at a dose of $\mathrm{N}_{60} \mathrm{P}_{60} \mathrm{~K}_{60}$ and 4.6 rubles on the option without the introduction of mineral fertilizers, the level of profitability ranged from $170 \%$ to $115 \%$, respectively. The Dobroe variety has a prime cost of 4.0 rubles in the variant with the main application of mineral fertilizers at a dose of $\mathrm{N}_{60} \mathrm{P}_{60} \mathrm{~K}_{60}$ and 5.7 rubles without mineral fertilizers with a profitability of $153 \%$ and $77 \%$, respectively. The Savva variety showed good results: 4.2 rubles with the main introduction of $\mathrm{P}_{60} \mathrm{~K}_{60}$ and 4.5 rubles for the option without mineral nutrition, the profitability level is $140 \%$ and $124 \%$, respectively. 
In connection with the above data, triticale can be considered as a culture that meets the resource-saving requirements of modern production against the background of various technological solutions. Low production costs and high yields determine the economic efficiency of cultivation, availability for most producers. Triticale is an excellent choice for ecological farming and allows you to solve any problems to improve and stabilize the feed base of livestock in the NonChernozem zone.

\section{References}

1. R. L. Villareal, G. Varughese, O. S. Abdalla, Advances in spring triticale breeding II Plant Breed. Rev. 8 (1990).

2. A. G. Abramova, K. N. Gorpinchenko. Economic assessment of the resource potential of agriculture in the Krasnodar Territory, In collection: Scientific support of the agro-industrial complex. Collection of articles based on the materials of the X All-Russian Conference of Young Scientists dedicated to the 120th anniversary of I.S. Kosenko (2017). Retrieved from: https://cyberleninka.ru/article/n/urozhaynost-ieffektivnost-proizvodstva -zerna-ozimogoyachmenya-nachernozeme-vyschelochennomzapadnogo-predkavkazya (date of treatment $02 / 12 / 2020$

3. A.A. Zhuchenko, Adaptive plant growing (ecological and genetic foundations) theory and practice. Volume 1 (Publishing House Agrorus, Moscow, 2008)
4. Yu.A. Lapshin, S.I. Novoselov, A.V. Danilov, R.I. Zolotareva, Response of spring triticale varieties to application of mineral fertilizers, Agricultural science of the Euro-North-East, 21(5) (2020). (In Rus.) Retrieved from: http:// doi.org/10.30766/20729081.2020.21.5.571-579

5. V.A. Maksimov, R.I. Zolotareva, R.B. Maksimova, Influence of different doses of nitrogen fertilization on grain and fodder productivity of winter rye varieties in the conditions of the Republic of Mari El, Agricultural science of the Euro-North-East, 65(4) (2018). DOI: 10.30766 / 20729081.2018.65.4.36-41.

6. R.K. Ramazanova, A.E. Tursinbaeva, G.R. Kekilbaeva, A.E Matina, The effect of nitrogen fertilizers on productivity of spring triticale in the dry steppe zone of Kazakhstan, Agricultural science of the Euro-North-East, 62(1) (2018). (In Rus.) Retrieved from: https://doi.org/10.30766/20729081.2018.62.1.47-51

7. A.A. Zhuchenko, Resource potential of grain production in Russia (theory and practice) (Publishing House Agrorus, Moscow, 2004).

8. A.I. Grigoriev (ed.), Methodology for state variety testing of agricultural crops. Second edition: cereals, cereals, legumes, corn and fodder crops (Kolos, Moscow, 1989)

9. T.P. Kokurin, N.N. Prokhorova, N.V. Rudnitsky, Methodological guidelines for calculating the economic efficiency of using the results of research work in agriculture for the conditions of the NorthEast of the European part of the Russian Federation (Kirov, 2008) 